\title{
PERANCANGAN JARINGAN NIRKABEL SEBAGAI REDUNDANCY LINK PADA INFRASTRUKTUR WAN YAYASAN KESEHATAN (YAKES) TELKOM BANDUNG MENGGUNAKAN METODOLOGI NETWORK DEVELOPMENT LIFE CYCLE (NDLC)
}

\section{WIRELESS NETWORK DESIGN AS REDUNDANCY LINK IN WAN INFRASTRUCTURE OF YAYASAN KESEHATAN (YAKES) TELKOM BANDUNG WITH NETWORK DEVELOPMENT LIFE CYCLE (NDLC) METHODOLOGY}

\author{
${ }^{1}$ Nolanda Indria, ${ }^{2} \mathrm{M}$. Teguh Kurniawan \\ 1,2.Program Studi Sistem Informasi, Fakultas Rekayasa Industri, Telkom University \\ 'nolan.indria@gmail.com, ${ }^{2} \mathrm{mtk} @$ telkomuniversity.ac.id
}

\begin{abstract}
Abstrak - Yayasan Kesehatan (YAKES) Telkom merupakan instansi kesehatan yang memberikan layanan kesehatan kepada seluruh karyawan dan pensiunan Telkom beserta keluarga inti. YAKES Telkom telah menerapkan infrastruktur WAN untuk mendukung proses bisnisnya. Namun, dalam penerapannya, infrastruktur WAN masih menggunakan single link. Single link merupakan kondisi di mana hanya terdapat satu jalur aliran data dalam mengakses server. Sehingga, ketika jalur tersebut mati, tidak terdapat jalur aliran data lainnya yang berfungsi sebagai jalur alternatif, yang mengakibatkan akses ke server tidak dapat dilakukan. Berdasarkan kondisi tersebut, maka dibutuhkan desain jaringan baru sebagai backup link. Desain jaringan ini berupa desain jaringan nirkabel, yaitu wireless outdoor yang menggunakan metodologi Network Development Life Cycle (NDLC). Metodologi ini melalui tahap analisis, tahap desain, dan tahap simulasi prototyping. Tujuan perancangan desain jaringan nirkabel adalah untuk melakukan optimasi pada infrastruktur WAN saat ini, yang nantinya akan berdampak terhadap proses bisnis. Hasil akhir dari penelitian ini adalah usulan rancangan desain jaringan nirkabel yang digunakan sebagai redundancy link WAN Yakes Telkom, di mana dalam pengujiannya dapat menggunakan dua metode untuk merepresentasikan koneksi wireless, yaitu metode bridging dan metode routing.
\end{abstract}

Kata kunci: Jaringan Nirkabel, WAN, Redundancy Link, NDLC.

Abstract - Yayasan Kesehatan (YAKES) Telkom is a health institution that provides healthcare services to all Telkom employees, retirees, and their nuclear family. YAKES Telkom has implemented a WAN infrastructure to support its business processes. However, in its application, WAN infrastructure still uses single link. Single link is a

$\begin{array}{ll}\text { Sejarah artikel } & \\ \text { Diterima redaksi: } & : 20 \text { Mei } 2017 \\ \text { Revisi akhir } & : 21 \text { Juli } 2017 \\ \text { Diterbitkan online } & : 21 \text { Desember } 2017\end{array}$

Thus, when the path is off, there is no other data stream path that serves as an alternative path, which causes access to the server cannot be done. Based on these conditions, it takes a new network design as backup links. The design of this network is wireless network design, which is wireless outdoor using Network Development Life Cycle (NDLC) methodology. This methodology is through the analysis phase, the design stage, and the prototyping simulation phase. The design goal of wireless network design is to optimize the current WAN infrastructure, which will make some impact towards business processes. The final result of this research is that the proposed wireless network design used as redundancy link WAN Yakes Telkom, could use two methods to represent wireless connection, they are bridging method and routing method.

Keywords: Wireless Network, WAN, Redundancy Link, NDLC.

\section{PENDAHULUAN}

Teknologi Informasi (TI) dapat berjalan dengan optimal jika didukung oleh perancangan infrastruktur jaringan yang matang. Infrastruktur jaringan yang dirancang dengan baik akan menentukan kualitas TI yang dihasilkan. Saat ini, infrastruktur jaringan telah berkembang pesat, yang dulunya menggunakan infrastruktur jaringan berbasis kabel kini telah berkembang ke infrastruktur jaringan berbasis nirkabel atau yang sering disebut jaringan wireless. Jaringan wireless menggunakan gelombang berfrekuensi tinggi sehingga komputerkomputer bisa saling terhubung tanpa menggunakan kabel. Infrastruktur jaringan nirkabel mempunyai beberapa kelebihan dibandingakan infrastruktur jaringan kabel, yaitu mobility, scalability, installation speed and simplicity, installation flexibility, reduced cost of ownership [1]. 
Salah satu instansi yang membutuhkan pembangunan infrastruktur jaringan yang baik adalah instansi di bidang kesehatan. Hal ini diperkuat dengan Peraturan Menteri Kesehatan Republik Indonesia Nomor 92 tahun 2014 tentang Penyelenggaraan Komunikasi Data dalam Sistem Informasi Kesehatan Terintegrasi pada Pasal 2, yang salah satu tujuannya adalah menjamin ketersediaan, kualitas dan akses data kesehatan priorias, dan muatan data lainnya.

Yayasan Kesehatan Telkom (YAKES) Telkom merupakan instansi kesehatan yang memberikan layanan kesehatan kepada seluruh karyawan dan pensiunan Telkom beserta keluarga inti. Dalam mendukung aktivitas proses bisnisnya, Yakes Telkom telah menerapkan infrastruktur jaringan berbasis kabel dan nirkabel di kantor pusat dan di setiap TPKK, sedangkan infrastruktur WAN menggunakan teknologi VPN IP yang disediakan oleh PT. Telkom Indonesia. Namun, dalam penerapan infrastruktur jaringan pada Yakes Telkom terdapat beberapa masalah, di antaranya belum adanya redundancy link sebagai backup link. Apabila terjadi gangguan pada jaringan core, yaitu pada VPN atau pada salah satu jalur VPN seperti jalur ke server di kantor pusat, maka aplikasi yang bersifat transaksional seperti medical record dan e-apotek tidak dapat diakses oleh TPKK. Hal tersebut dapat mengganggu jalannya aktivitas proses bisnis yang ada di Yakes Telkom. Redundancy link dapat mengatasi masalah putusnya atau terdapat gangguan pada media transmisi yang mengakibatkan hilangnya koneksi jaringan. Dengan adanya sistem redundancy link, koneksi akan lebih terjaga karena apabila salah satu link mati atau terputus, proses komunikasi akan tetap berlangsung karena masih terdapat link cadangan yang akan mengakomodasi proses komunikasi [2].

Berdasarkan kondisi jaringan tersebut, maka diperlukan rancangan infrastruktur jaringan nirkabel dengan teknologi wireless outdoor sebagai backup link. perancangan infrastruktur ini menggunakan metode NDLC (Network Development Life Cycle) dan model Cisco three-layer hierarchical.

\section{STUDI LITERATUR}

\section{A. Wireless outdoor}

Wireless outdoor digunakan untuk menghubungkan dua lokasi yang jaraknya berjauhan. Dengan menggunakan wireless outdoor dapat melakukan pengiriman data, file, dan informasi dari beberapa lokasi yang berjauhan secara point-to-point maupun point-to-multipoint [3].

\section{B. Line of sight (LOS)}

Dalam membangun jaringan wireless outdoor salah satu yang harus diperhatikan adalah ada atau tidaknya yang menghalangi jalur pemancaran sinyal dari satu antena ke antena lainnya. Ketika tidak ada penghalang pemancaran sinyal dari kedua antena, kondisi tersebut dikenal sebagai line of sight. Line of sight dibagi menjadi tiga bagian, yaitu jalur Full Line of Sight (LOS) merupakan kondisi di mana tidak ada hambatan di antara kedua antena. Yang kedua adalah Near Line of Sight (nLOS) merupakan kondisi di mana terdapat penghalang parsial seperti puncak pohon, gedung antara dua antena. Yang terakhir adalah Non Line of Sight (NLOS) merupakan kondisi di mana terdapat penghalang penuh di antara dua antena [4].

\section{Fresnel zone}

Fresnel zone adalah area di sekitar LOS antarperangkat wireless yang digunakan sebagai area media rambat frekuensi. Area fresnel zone harus bebas dari halangan baik berupa bangunan dan juga pepohonan. Kekuatan sinyal akan menurun jika ada yang menghalangi pada area fresnel zone. Untuk mendapatkan fresnel zone yang bebas dari gangguan adalah dengan menaikkan ketinggian peletakan tower antena [5].

\section{Cisco three-layered hierarchical model}

Three-layerered hierarchical model adalah pendekatan yang digunakan untuk mencapai kinerja yang tinggi, ketersediaan yang tinggi dan jaringan yang scalable. Hierarchical network design model memecah masalah yang kompleks pada desain jaringan menjadi lebih kecil dah lebih mudah dikelola. Setiap tingkat memiliki peran yang berbeda. Hal ini dapat membantu mengoptimalkan perangkat jaringan untuk melakukan peran tertentu [6].

Berikut tiga layer pada Cisco three-layered hierarchical model:
1. Core layer
2. Distribution layer
3. Access layer

\section{METODOLOGI PENELITIAN}

\section{A. Network Development Life Cycle (NDLC)}

Network Development Life Cyle (NDLC) merupakan suatu metode yang digunakan dalam mengembangkan atau merancang jaringan infrastruktur yang memungkinkan terjadinya pemantauan jaringan untuk mengetahui statistik dan kinerja jaringan. Hasil analisis kinerja tersebut dijadikan sebagai pertimbangan dalam perancangan desain jaringan, baik desain jaringan yang bersifat fisik atau jaringan logis [7]. Gambar 1 menunjukkan tahapan dari NDLC, yaitu analysis, design, simulation prototyping, implementation, monitoring dan management.

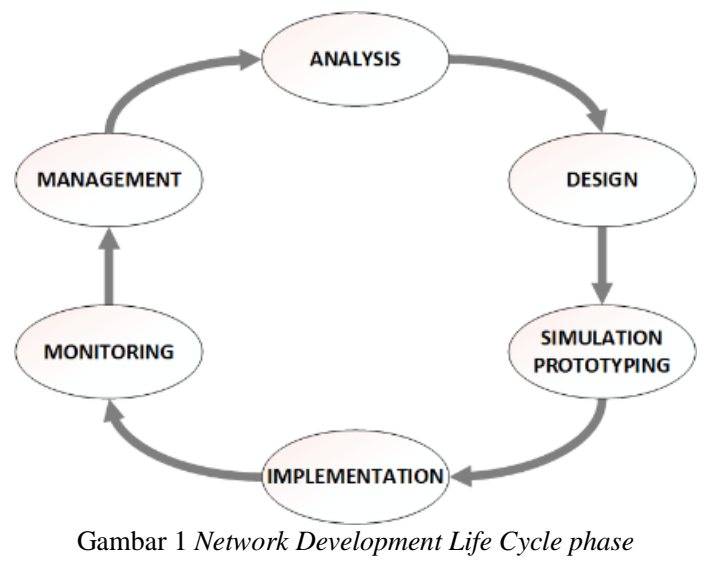

Pada penelitian ini menggunakan tiga tahapan pada metodologi NDLC, yaitu:

1. Analysis

Tahap ini menganalisis masalah kondisi WAN pada Yakes Telkom Bandung dan menemukan solusinya. Hal 
ini dilakukan untuk menjadi acuan dalam melakukan perancangan desain jaringan usulan.

2. Design

Tahap ini melakukan perancangan usulan desain jaringan, yaitu jaringan nirkabel sebagai solusi dari permasalahan yang ditemukan pada tahap analisis.

3. Simulation prototyping

Tahap ini melakukan pengujian redundancy link pada desain jaringan nirkabel yang telah dibuat.

\section{B. Model Konseptual}

Metodologi penelitian dapat berupa kerangka atau model konseptual yang digunakan dalam penelitian [8]. Proses konseptual model membutuhkan kepastian dalam menentukan sebuah ruang lingkup dan tingkatan model secara rinci [9]. Pada penelitian ini model konseptual yang digunakan dapat dilihat pada Gambar 2.

Gambar 2 menjelaskan penelitian didasari oleh permasalahan yang ada pada Yakes Telkom Bandung, yaitu belum adanya redundancy link sebagai backup link ketika jaringan core mengalami gangguan. Hal ini dapat menghambat aliran data saat terjadinya gangguan. Pelaku yang terlibat dalam penelitian ini adalah pegawai Yakes Telkom, baik yang berada di kantor pusat maupun di TPKK. Pegawai Yakes Telkom menggunakan beberapa aplikasi yang saling terintegrasi dalam menjalankan aktivitas proses bisnisnya, di antaranya web Yakes, interface HRIS-SIKA, absensi, cuti, HRIS, SIKA, survey kepuasan peserta, queuing, medrec, DAKEM, DOC, SISFOKUG, e-Apotek, SIMLOG, DOT, dan SIM investasi.

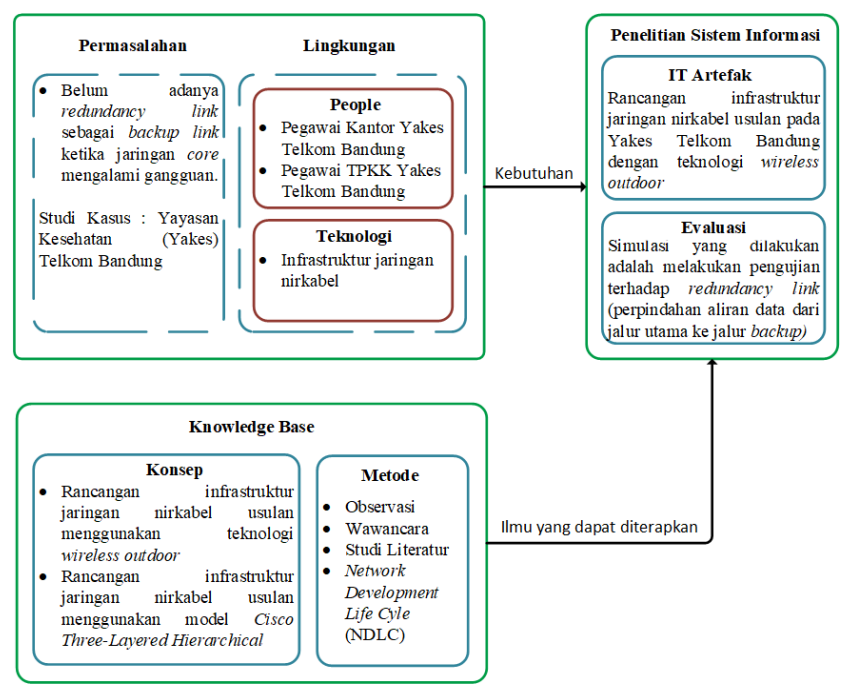

Penelitian menggunakan konsep teknologi wireless outdoor, serta mengacu kepada model Cisco three-layered hierarchical. Untuk mendukung penelitian ini dibutuhkan beberapa informasi yang diperoleh dengan menggunakan metode observasi, wawancara, dan studi literatur. Selain itu, metode yang digunakan dalam penelitian ini adalah metode Network Development Life Cycle (NDLC).

Penelitian ini menghasilkan sebuah rancangan infrastruktur jaringan nirkabel dengan teknologi wireless outdoor. Untuk mengevaluasi rancangan tersebut, dilakukan simulasi dengan melakukan pengujian terhadap redundancy link, yaitu proses perpindahan aliran data dari jalur utama ke jalur backup.

\section{HASIL DAN ANALISIS}

A. Kondisi jaringan saat ini

Jaringan pada Yakes Telkom terdiri dari dua jenis, yaitu LAN (Local Area Network) dan WAN (Wide Area Network). LAN merupakan jaringan yang berada di kantor dan setiap TPKK Yakes Telkom. Sedangkan WAN merupakan jaringan yang menghubungkan kantor dan setiap TPKK Yakes Telkom. Gambar 3 menunjukkan topologi WAN Yakes Telkom Bandung saat ini.

Mengacu pada topologi WAN Yakes Telkom Bandung pada Gambar 3, kantor pusat dan setiap TPKK Yakes Telkom dihubungkan oleh satu jaringan VPN IP. Namun, jaringan VPN IP masih bersifat single link. Single link dapat dikatakan tidak adanya redundancy link yang berfungsi sebagai backup link saat terjadi gangguan pada salah satu link. Hal ini menyebabkan seluruh aplikasi dan database yang bersifat terpusat di kantor pusat Yakes Telkom tidak dapat diakses.

\section{B. Perancangan desain jaringan usulan}

Desain jaringan usulan merupakan rancangan jaringan nirkabel menggunakan teknologi wireless outdoor yang menghubungkan kantor pusat dengan setiap TPKK di Bandung. Jaringan wireless outdoor yang diusulkan bersifat intranet, sehingga tidak membutuhkan pengadaan bandwidth yang akan mengeluarkan biaya lebih besar. Selain itu proses instalasi juga mudah dan cepat. Perancangan wireless outdoor menggunakan koneksi point-to-multipoint dimana kantor pusat menjadi access point dan setiap TPKK menjadi station. Tabel I menunjukkan lokasi kantor pusat dan TPKK Yakes Telkom Bandung. 


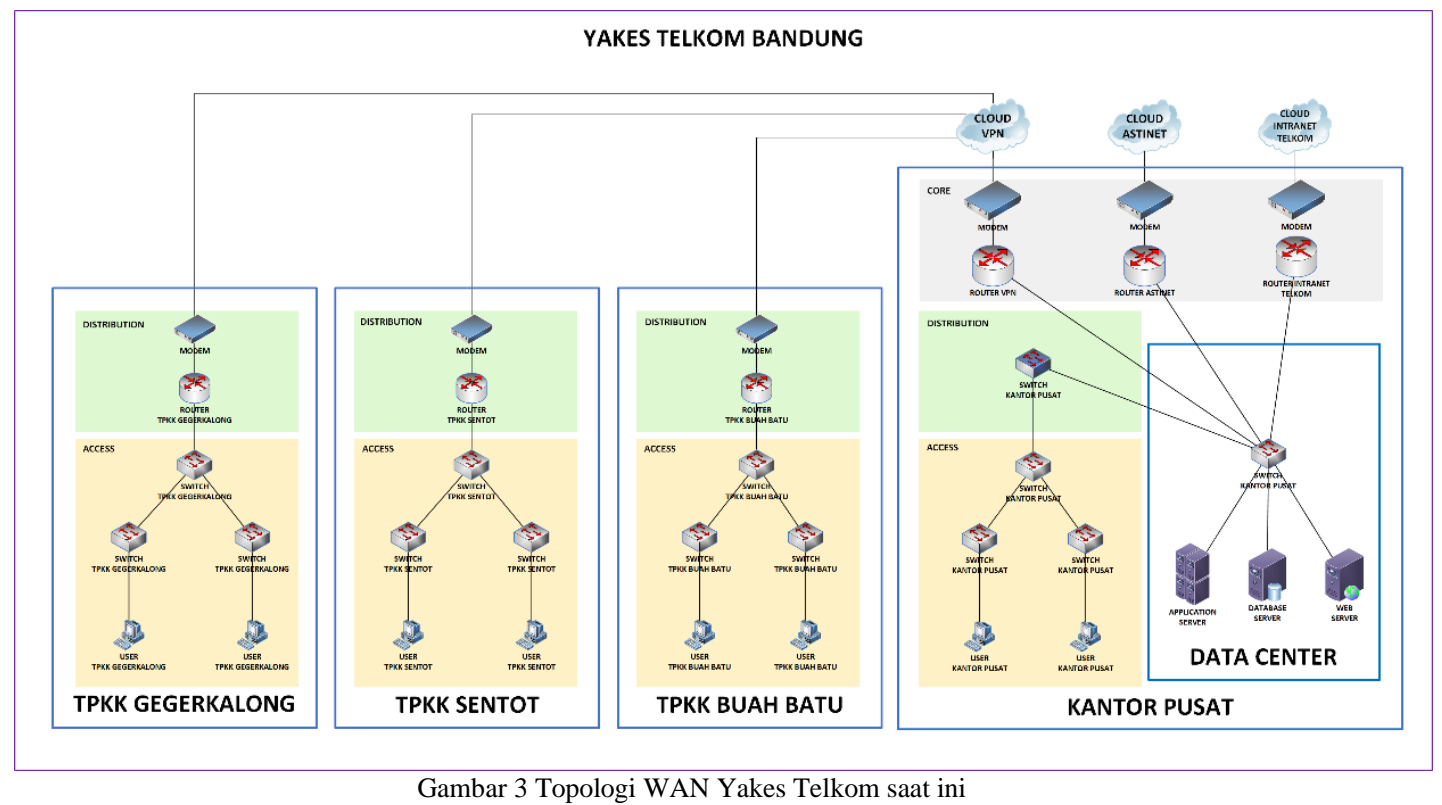

TABEL I

KOORDINAT LOKASI YAKES TELKOM BANDUNG

\begin{tabular}{ccccc}
\hline No. & $\begin{array}{c}\text { Nama } \\
\text { Lokasi }\end{array}$ & Latitude & Longitude & Elevasi \\
\hline 1. & $\begin{array}{c}\text { Kantor } \\
\text { Pusat }\end{array}$ & -6.903784 & 107.620554 & $728 \mathrm{~m}$ \\
& $\begin{array}{c}\text { TPKK } \\
\text { 2. }\end{array}$ & -6.870166 & 107.590095 & $867 \mathrm{~m}$ \\
& $\begin{array}{c}\text { Gegkalong } \\
\text { TPKK }\end{array}$ & -6.899936 & 107.61945 & $743 \mathrm{~m}$ \\
& $\begin{array}{c}\text { Sentot } \\
\text { TPKK Buah } \\
\text { Batu }\end{array}$ & -6.950900 & 107.637137 & $678 \mathrm{~m}$ \\
\hline
\end{tabular}

Dalam perancangan wireless outdoor, hal yang harus diperhatikan adalah kondisi line of sight antara antena access point dan antena setiap station. Kondisi line of sight dari antena access point dan antena setiap station menjadi acuan dalam perancangan topologi jaringan nirkabel usulan menggunakan wireless outdoor.

\section{Station TPKK Gegerkalong}

Gambar 4 menunjukkan kondisi line-of-sight antara access point pada kantor pusat dan station TPKK Gegerkalong. Garis merah menggambarkan halangan terbesar antara access point dan station. Warna biru menggambarkan area yang harus bebas dari halangan yang digunakan sebagai area media rambat frekuensi, yang biasa disebut sebagai fresnel zone. Warna hijau menggambarkan halangan antarantena. Warna cokelat menggambarkan ketinggian kontur tanah. Untuk mendapatkan kondisi full line-of-sight, minimum ketinggian peletakan antena access point pada kantor pusat adalah sebesar enam puluh meter di atas permukaan tanah. Sedangkan, minimum ketinggian peletakan antena station TPKK Gegerkalong adalah sebesar sepuluh meter di atas permukaan tanah. Selanjutnya, Gambar 4 menunjukkan jarak antara kantor pusat Yakes Telkom dengan TPKK Gegerkalong adalah kurang lebih lima kilometer.

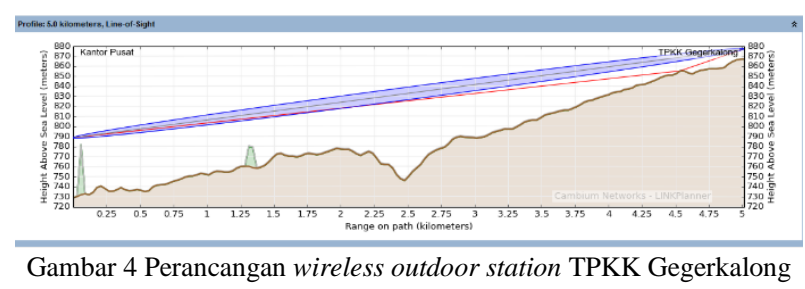

2. Station TPKK Sentot

Gambar 5 menunjukkan menunjukkan kondisi line-ofsight antara access point pada kantor pusat dan station TPKK Sentot. Untuk mendapatkan kondisi full line-ofsight, minimum ketinggian peletakan antena access point pada kantor pusat adalah sebesar enam puluh meter di atas permukaan tanah. Sedangkan, minimum ketinggian peletakan antena station TPKK Sentot adalah sebesar sepuluh meter di atas permukaan tanah. Selanjutnya, Gambar 5 menunjukkan jarak antara kantor pusat Yakes Telkom dengan TPKK Sentot adalah kurang lebih 0,4 kilometer.

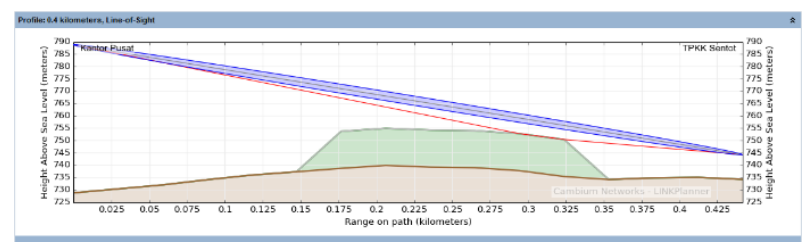

Gambar 5 Perancangan wireless outdoor station TPKK Sentot

3. Station TPKK Buah Batu

Gambar 6 menunjukkan menunjukkan kondisi line-ofsight antara access point pada kantor pusat dan station TPKK Buah Batu. Untuk mendapatkan kondisi full lineof-sight, minimum ketinggian peletakan antena access point pada kantor pusat adalah sebesar enam puluh meter 
di atas permukaan tanah. Sedangkan, minimum ketinggian peletakan antena station TPKK Buah Batu adalah sebesar seratus sepuluh meter di atas permukaan tanah. Selanjutnya, Gambar 6 menunjukkan jarak antara kantor pusat Yakes Telkom dengan TPKK Buah Batu adalah kurang lebih 5,5 kilometer.

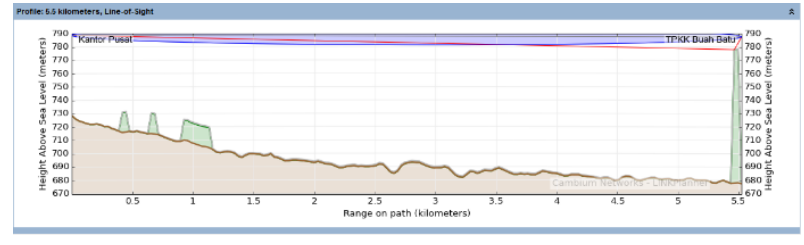

Gambar 6 Perancangan wireless outdoor station TPKK Buah Batu

\section{Topologi jaringan nirkabel usulan}

Jaringan wireless outdoor dirancang sebagai redundancy link, di mana terdapat tiga redundancy link usulan, yaitu link yang menghubungkan antara kantor pusat dengan TPKK Sentot, link yang menghubungkan antara kantor pusat dengan TPKK Gegerkalong, dan link yang menghubungkan kantor pusat dengan TPKK Buah Batu. Gambar 7 menunjukkan topologi jaringan nirkabel usulan pada WAN Yakes Telkom Bandung. Desain topologi jaringan nirkabel digambarkan berdasarkan Cisco three-layered hierarchical model. Setiap warna menggambarkan layer yang berbeda. Warna abu-abu merupakan core layer, warna hijau merupakan distribution layer, dan warna kuning merupakan access layer.

\section{Perangkat jaringan nirkabel usulan}

Perangkat jaringan yang diusulkan adalah built in hardware Mikrotik, merupakan Mikrotik dalam bentuk perangkat keras yang khusus dikemas dalam board router atau biasa dikenal sebagai RouterBoard di mana di dalamnya sudah terinstal sistem operasi Mikrotik RouterOS. RouterBoard menggunakan OS RouterOS yang berfungsi sebagai router jaringan, bandwidth management, proxy server, DHCP, DNS server dan hotspot server [10].

Pada core layer diusulkan perangkat Mikrotik Routerboard RB433AH. Perangkat ini memiliki lisensi level lima sehingga dapat mendukung access point dan bridge access point Perangkat ini memiliki tiga slot mini PCI sehingga dapat dikustomisasi sesuai kebutuhan Yakes Telkom.

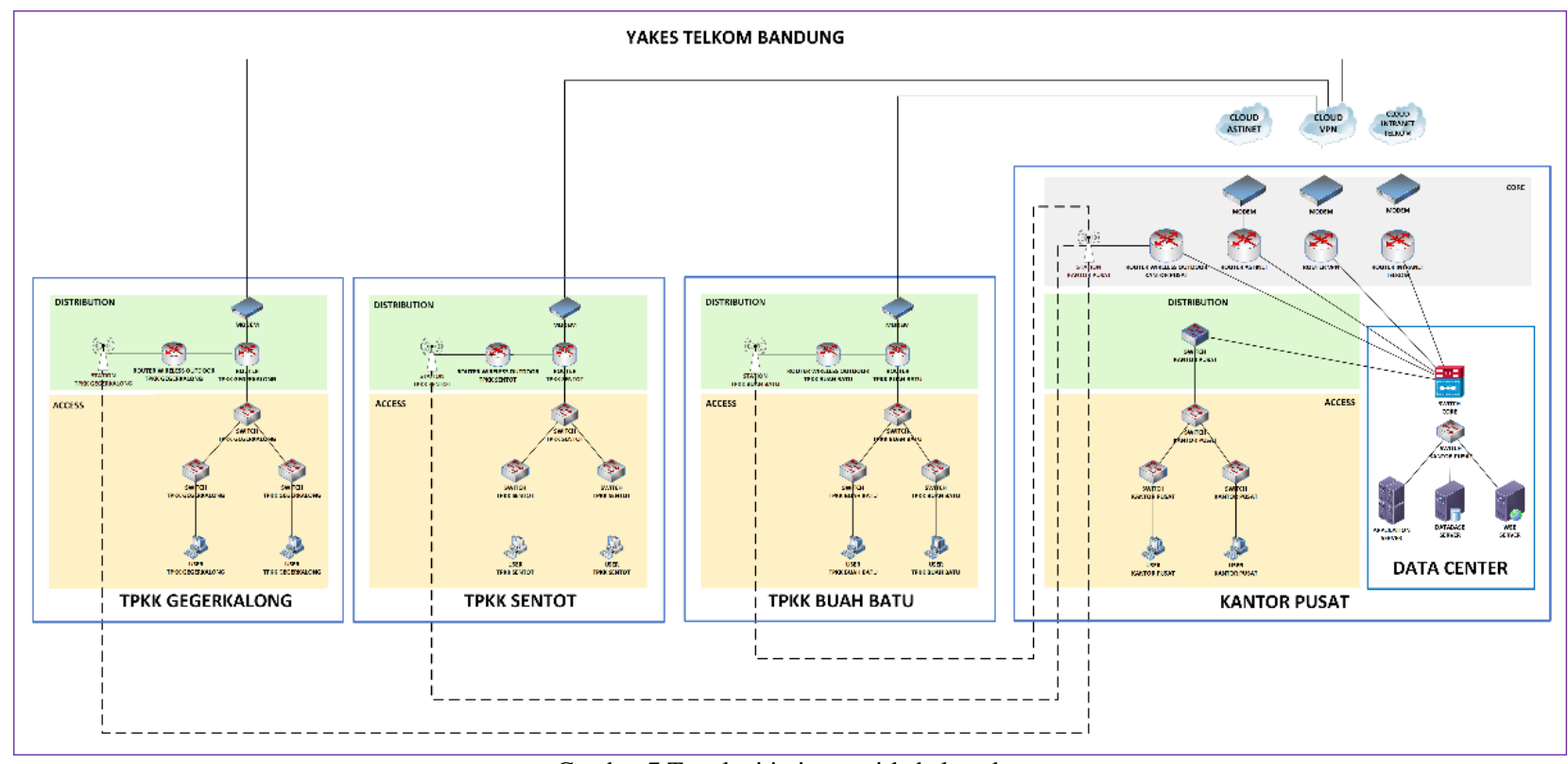

Gambar 7 Topologi jaringan nirkabel usulan

Pada distribution layer, diusulkan perangkat Mikrotik Routerboard RBSXT-5nDr2. Perangkat ini memiliki lisensi level tiga yang dapat mendukung sebagai client atau station. Mikrotik Routerboard RBSXT-5nDr2 sangat efisien, karena perangkat ini sudah termasuk antena dengan gain $16 \mathrm{dBi}$.

Antena yang diusulkan adalah grid antenna. Grid antenna cocok digunakan untuk mengatasi kendala komunikasi dan mengirimkan transmisi secara efektif. Sudut pola pancaran antena ini lebih fokus pada titik tertentu sesuai pemasangannya [11].
E. Pengujian redundancy link topologi jaringan nirkabel usulan

Pengujian redundancy link merupakan pengujian terhadap perpindahan aliran data dari jalur utama VPN IP ke jalur backup yaitu wireless outdoor. Model koneksi wireless direpresentasikan dalam IP layer. Dalam merepresentasikan koneksi wireless access point dan wireless station dapat menggunakan dua metode, yaitu metode bridging dan metode routing.

Pengujian redundancy link bertujuan untuk melihat rute aliran data dari end user di setiap TPKK menuju server pada 
kantor pusat. Rute yang dilihat adalah ketika jalur utama menuju server aktif dan ketika jalur utama menuju server, down.

Dalam merepresentasikan terjadinya gangguan pada jalur utama VPN IP, dilakukan pematian interface di setiap router TPKK yang menuju jalur utama pada topologi jaringan nirkabel.

1. Pengujian redundancy link topologi jaringan nirkabel menggunakan metode bridging

Pada skenario pengujian ini, access point pada kantor pusat dikonfigurasi menggunakan metode bridge, sehingga access point dan setiap station akan berada pada satu broadcast domain yang sama. Pada pengujian ini menggunakan sample TPKK Gegerkalong sebagai end user yang mengakses server. Gambar 10 menunjukkan topologi perngujian redundancy link pada topologi jaringan nirkabel menggunakan metode bridging.

a. Aliran data melewati jalur utama

Hal pertama yang dilakukan adalah memeriksa jalur utama VPN IP menuju server masih aktif.

Gambar 8 menunjukkan status interface fastethernet $1 / 0$ adalah up. Interface fastethernet $1 / 0$ merupakan interface menuju jalur utama VPN IP. Status up menandakan bahwa jalur utama aktif. Selanjutnya adalah melihat rute aliran data dari end user TPKK Gegerkalong menuju server.

Gambar 9 menunjukkan bahwa rute aliran data dari TPKK Gegerkalong menuju server dengan alamat IP 10.15.2.2 melewati 172.172.3.10 yang merupakan jalur utama VPN IP.

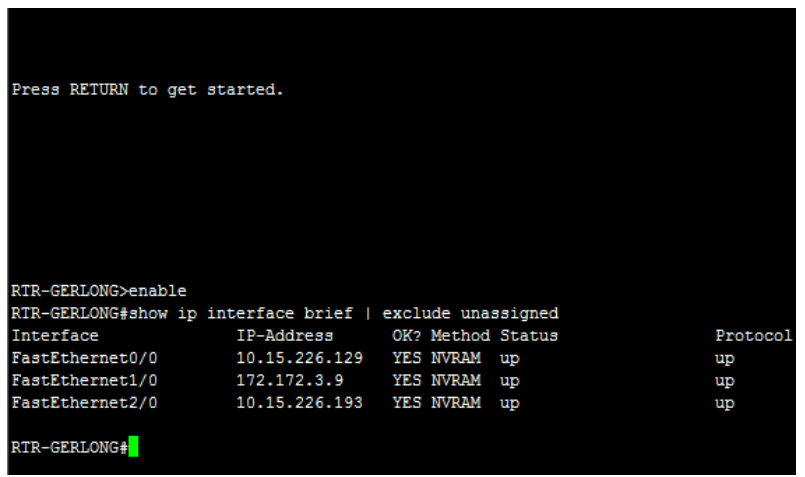

Gambar 8 Jalur utama VPN IP TPKK Gegerkalong aktif

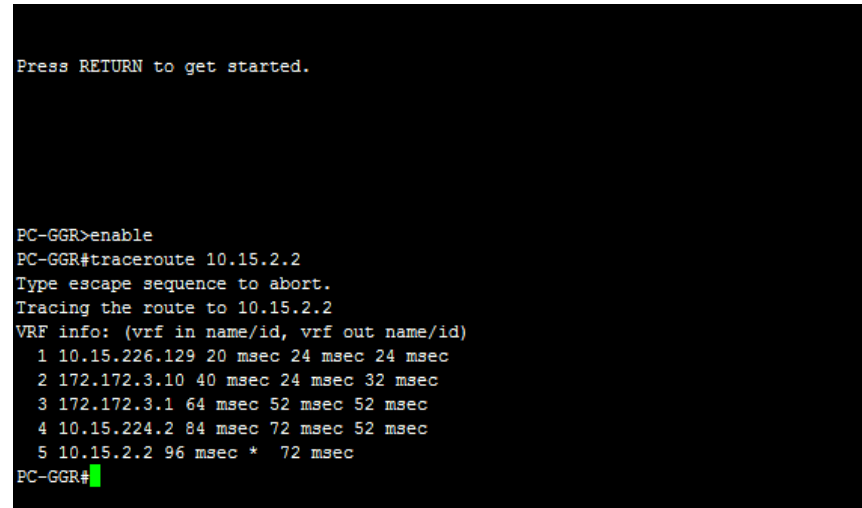

Gambar 9 Rute pengiriman paket TPKK Gegerkalong melalui jalur utama

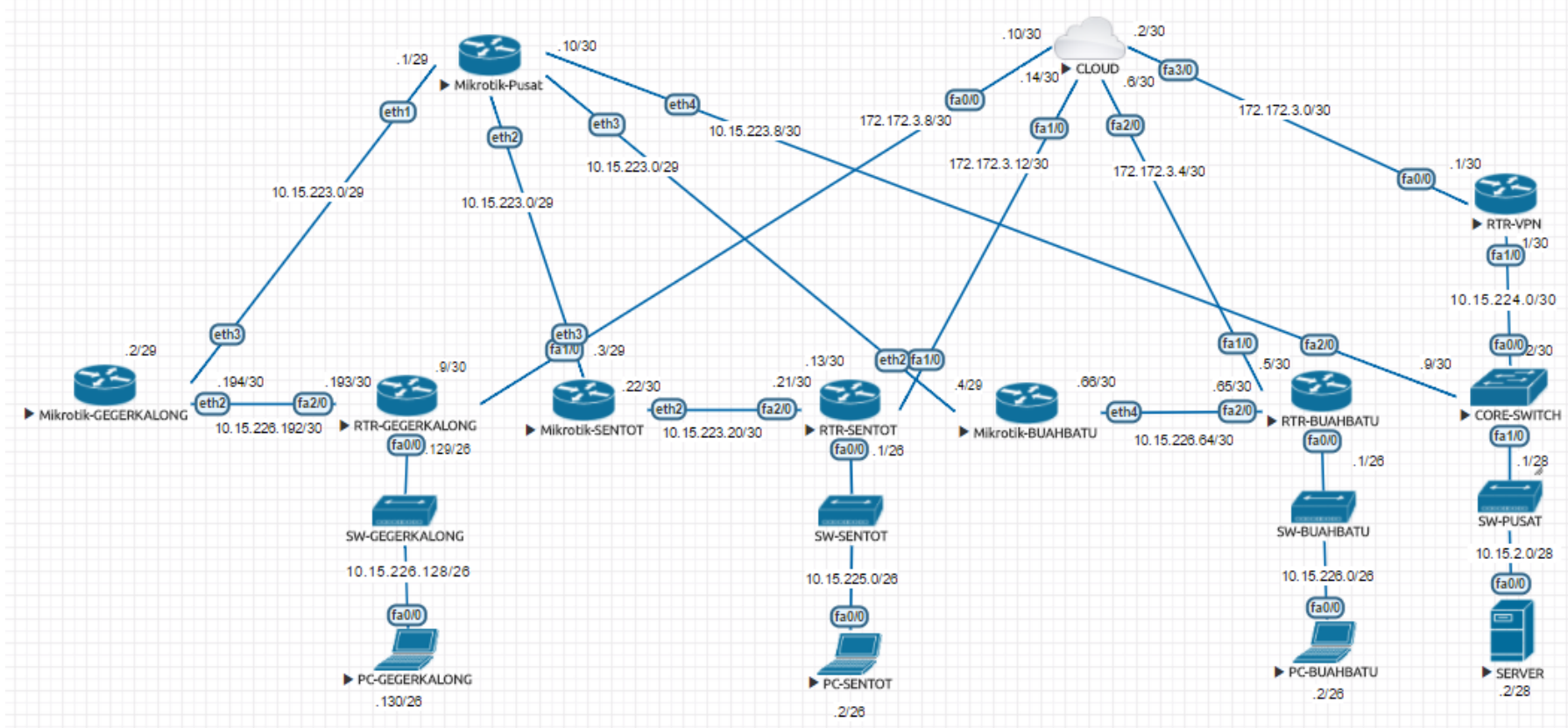

Gambar 10 Topologi simulasi jaringan nirkabel usulan metode bridging 
b. Aliran data melewati jalur backup

Hal pertama yang dilakukan adalah memastikan bahwa jalur utama VPN IP menuju server, down.

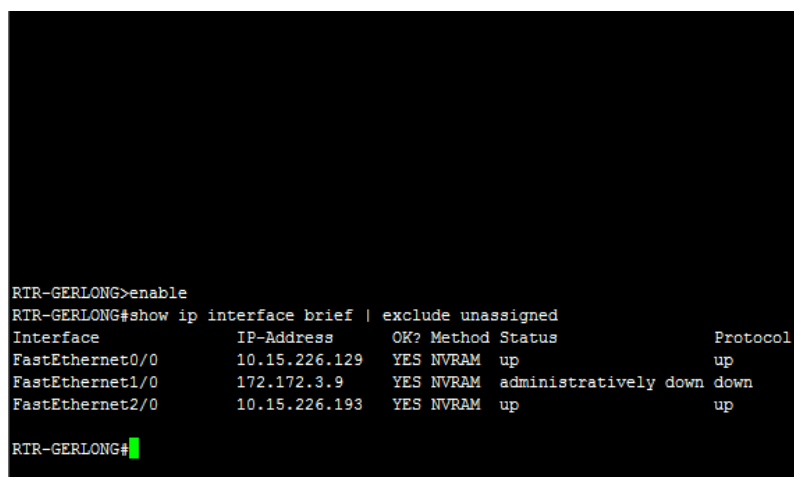

Gambar 11 Jalur utama VPN IP TPKK Gegerkalong down

Gambar 11 menujukkan status interface fastethernet 1/0 adalah down. Interface fastethernet 1/0 merupakan interface menuju jalur utama VPN IP. Status down menandakan bahwa jalur utama tidak aktif. Selanjutnya adalah melihat rute aliran data dari end user TPKK Gegerkalong menuju server.

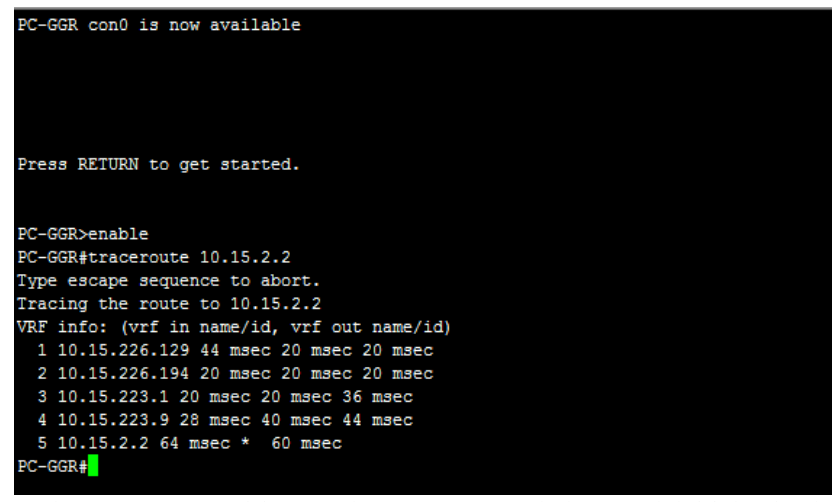

Gambar 12 Rute pengiriman paket TPKK Gegerkalong melalui jalur backup ketika jalur utama down

Gambar 12 menunjukkan bahwa rute aliran data dari TPKK Gegerkalong menuju server dengan alamat IP 10.15.2.2 melewati 10.15.226.194, kemudian melewati 10.15.223.1 yang merupakan jalur backup usulan. Aliran data dari TPKK Gegerkalong yang awalnya melalui jalur utama dialihkan ke jalur backup ketika jalur utama VPN IP down.

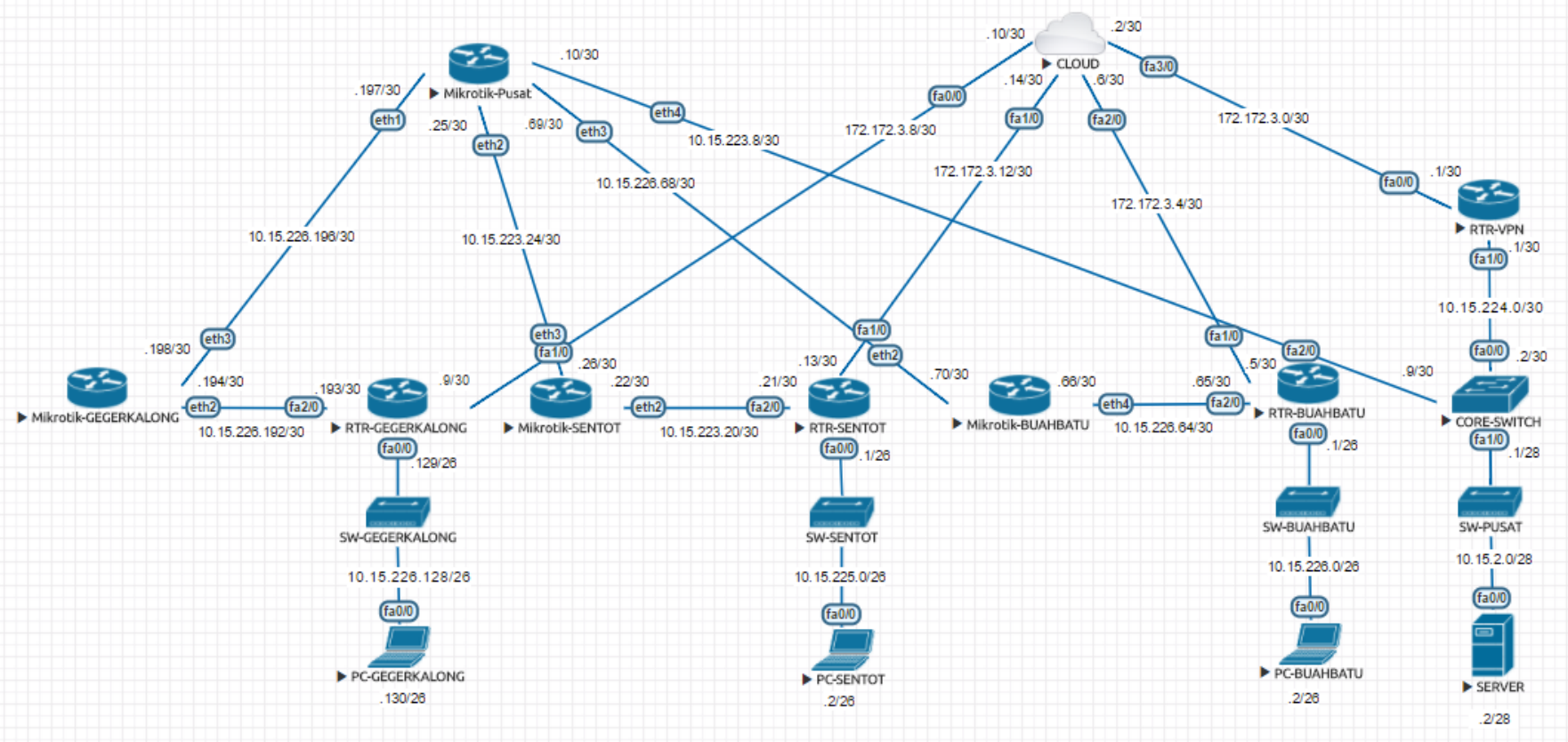

Gambar 13 Topologi simulasi jaringan nirkabel usulan metode routing

2. Pengujian redundancy link topologi jaringan nirkabel menggunakan metode routing

Pada skenario pengujian ini, untuk merepresentasikan koneksi access point dan station menggunakan metode routing, yaitu Open Shortest Path First (OSPF). Pada pengujian ini menggunakan sample TPKK Sentot sebagai end user yang mengakses server. Gambar 13 menunjukkan topologi pengujian redundancy link pada topologi jaringan nirkabel menggunakan metode routing.

\section{a. Aliran data melewati jalur utama}

Hal pertama yang dilakukan adalah memeriksa jalur utama VPN IP menuju server masih aktif. Gambar 14 menujukkan status interface fastethernet $1 / 0$ adalah up. Interface fastethernet 1/0 merupakan interface menuju jalur utama VPN IP. Status up menandakan bahwa jalur utama aktif. Selanjutnya adalah melihat rute aliran data dari end user TPKK Sentot menuju server. 


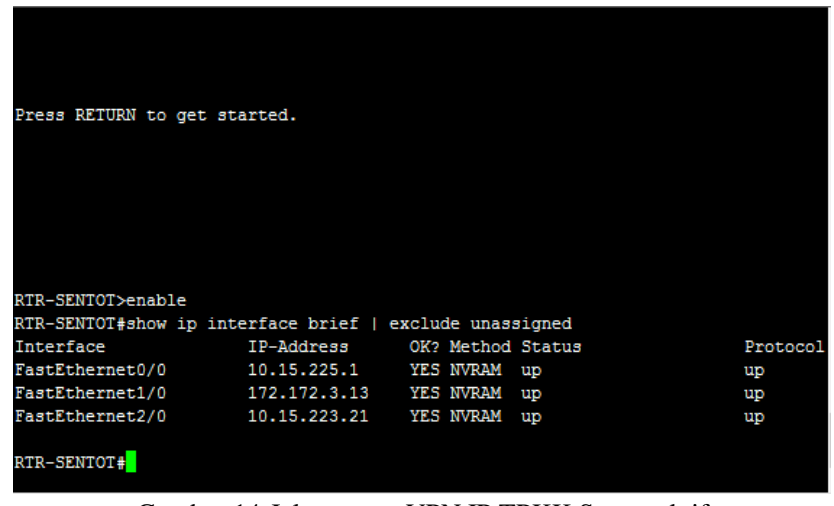

Gambar 14 Jalur utama VPN IP TPKK Sentot aktif

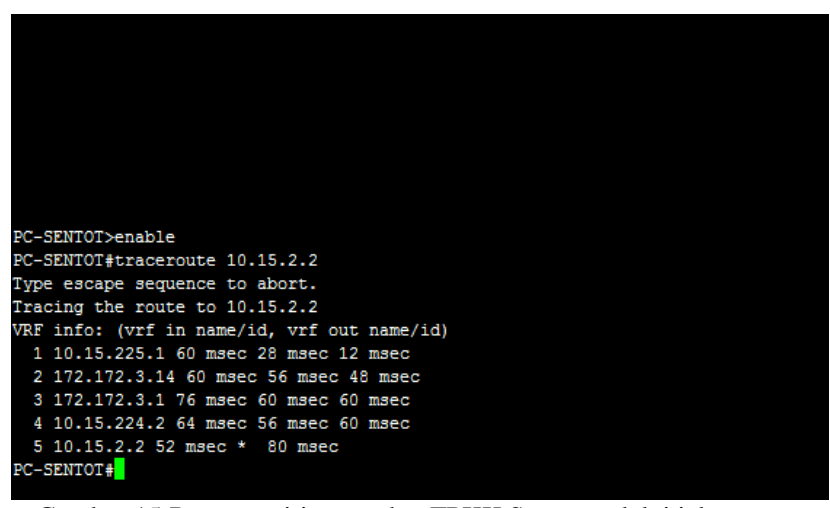

Gambar 15 Rute pengiriman paket TPKK Sentot melalui jalur utama

Gambar 15 menunjukkan bahwa rute aliran data dari TPKK Sentot menuju server dengan alamat IP 10.15.2.2 melewati 172.172.3.14 yang merupakan jalur utama VPN IP.

b. Aliran data melewati jalur backup

Hal pertama yang dilakukan adalah memastikan bahwa jalur utama VPN IP menuju server, down.

Gambar 16 menujukkan status interface fastethernet $1 / 0$ adalah down. Interface fastethernet 1/0 merupakan interface menuju jalur utama VPN IP. Status down menandakan bahwa jalur utama tidak aktif.

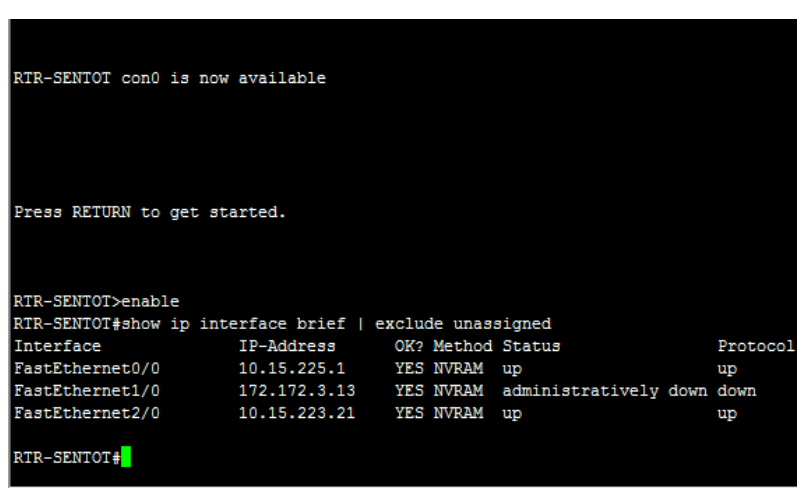

Gambar 16 Jalur utama VPN IP TPKK Sentot down

Selanjutnya adalah melihat rute aliran data dari end user TPKK Sentot menuju server.

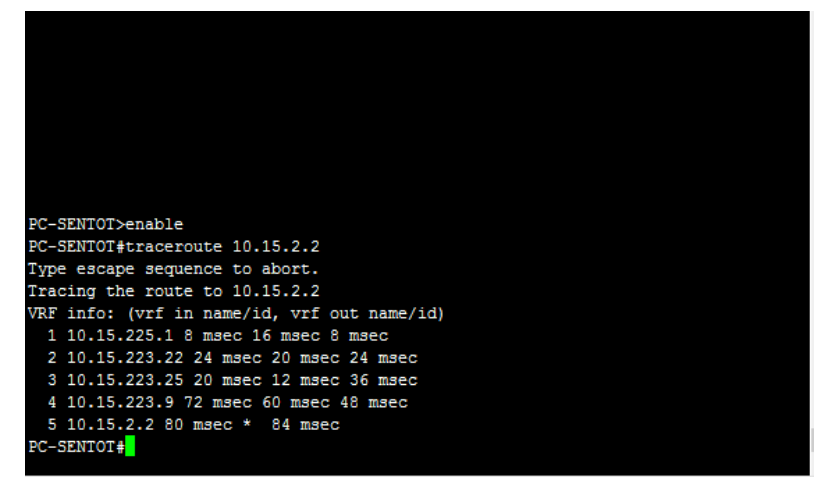

Gambar 17 Rute pengiriman paket TPKK Sentot melalui jalur backup ketika jalur utama down

Gambar 17 menunjukkan bahwa rute aliran data dari TPKK Sentot menuju server dengan alamat IP 10.15.2.2 melewati 10.15.223.22, kemudian melewati 10.15.223.25 yang merupakan jalur backup usulan. Aliran data dari TPKK Sentot yang awalnya melalui jalur utama dialihkan ke jalur backup ketika jalur utama VPN IP down.

\section{KESIMPULAN}

Berdasarkan analisis yang telah dilakukan, peneliti menyimpulkan bahwa, pada tahap identifikasi kondisi WAN Yakes Telkom Bandung ditemukan permasalahan, yaitu tingkat availability jaringan masih belum terpenuhi. Hal ini dikarenakan topologi WAN Yakes Telkom Bandung saat ini masih menggunakan single link. Kemudian, diusulkan perancangan jaringan nirkabel menggunakan teknologi wireless outdoor dengan koneksi point-to-multipoint sebagai jalur backup. Dalam pengujian topologi jaringan nirkabel usulan berfokus pada proses perpindahan aliran data dari jalur utama yaitu VPN IP ke jalur backup yaitu wireless outdoor. Pengujian topologi jaringan nirkabel usulan dapat menggunakan dua metode dalam merepresentasikan koneksi access point dan station, yaitu metode bridging dan metode routing. Dengan menggunakan metode bridging maka access point dan station akan berada pada broadcast domain yang sama. Selain itu penggunaan alamat IP lebih sedikit. Metode ini dapat digunakan untuk skala jaringan yang kecil. Sedangkan dengan menggunakan metode routing, akan menggunakan alamat IP yang lebih banyak dibanding metode bridging. Berdasarkan hasil pengujian topologi jaringan nirkabel usulan, menunjukkan bahwa perpindahan pengiriman data dari jalur utama VPN IP ke jalur backup berhasil diterapkan pada topologi jaringan nirkabel usulan. Infrastruktur WAN Yakes Telkom termasuk ke dalam skala jaringan yang kecil, maka cocok menggunakan metode bridging dalam koneksi wireless access point dan wireless station. Sehingga dapat menghemat penggunaan alamat IP. 


\section{DAFTAR PUSTAKA}

[1] S. Rumalutur, "Analisis Keamanan Jaringan Wireless LAN (WLAN pada PT. PLN (Persero) Wilayah P2B Area Sorong," Jurnal Teknologi dan Rekayasa, vol. 19, Desember 2014.

[2] R. Muhammad, M. Iqbal and R. Mayasari, "Implementasi dan Analisis Performa Bonding Interface Mode 802.3AD sebagai Link Redundancy pada Router Mikrotik," 2014.

[3] Arifin, "Wireless Outdoor sebagai Solusi Koneksi Internet di Daerah Terpencil pada PT.ABC," vol. 13, April 2012.

[4] L-Com, "Line of Sight (LOS)," [Online]. [Accessed 1 November 2016].

[5] B. Supradono, "Perhitungan Wireless LAN pada Jaringan WAN (Wide Area Network) untuk Komunikasi Data di 3 Kampus Universitas Muhammadiyah Semarang," vol. 1, pp. 20-24, 2008.

[6] Cisco, "The Hierarchical Network Design Model," 2003. [Online]. Available: http://www.cisco.com/web/learning/netacad/demos/CCN P1v30/ch1/1_1_1/index.html. [Accessed 1 November 2016].

[7] G. James, "Chapter 10: The Network Development Life Cycle," in Applied Data Communications : A BusinessOriented Approach, 2004, p. 375.

[8] Z. A. Hasibuan, Metodologi Penelitian pada Bidang Ilmu Komputer dan Teknologi Informasi, Depok: Universitas Indonesia, 2007.

[9] S. R. Kathy Kotiadis, "Conseptual Modelling: Knowledge Acquisition and Model Abstraction," IEEE, pp. 951-958, 2008.

[10]T. Raharjo, 10 Juni 2015. [Online]. Available: http://ebook.repo.mercubuanayogya.ac.id/FTI/tugas_doc_20142/13111052-

TIF46_P_11-Tugas\%20Elearning\%20Jarkom-13111052Tri\%20Raharjo.pdf. [Accessed 13 April 2017].

[11] A. Yuhanef, "Penguatan Sinyal Global System for Mobile Communication (GSM) $900 \mathrm{MHz}$ Menggunakan Antena Grid," Jurnal Elektron, vol. 5, Desember 2013. 